\title{
Effect of Eucalyptus Plantations on Soil Properties: The Case of Entoto Area, Northern Addis Ababa, Ethiopia
}

\author{
Amare Amsalu* \\ College of social science and humanities \\ Shegaw yesgat Hailu (coauthor) \\ School of social science and humanities, Dessie Ethiopia
}

\begin{abstract}
Eucalyptus species are blamed for negatively affecting the soil and inhibiting growth of other plants though it is extensively planted in Ethiopia. This study investigated the effect of Eucalyptus plantations on selected soil physical and chemical properties at Entoto Mountain, in the Northern part of the capital, Addis Ababa. Three landuses/covers (monoculture Eucalyptus plantations, cropland, and natural forests) with a plot size of 100x100m (1ha) each were used for comparison. Each experimental plot was sub-divided into three sub-plots of 100x33m for soil sampling. Sampling was done to $30 \mathrm{~cm}$ depth with soil auger. A study of people's perception on impacts of Eucalyptus was also undertaken to supplement the soil investigation. The soil samples were dried and analyzed while following standard procedures. One way ANOVA test result indicated that Eucalyptus plantations have significantly different effect on soil parameters such as texture (sand 35\%, silt $29 \%$ and clay $27.11 \%$ ), soil bulk density $\left(1.43 \mathrm{gcm}^{-3}\right), \mathrm{pH}$ level(5.32), total nitrogen (2.36\%), organic carbon (4.07\%), Available potassium (127.23 $\mathrm{ppm})$ and phosphors $(8.23 \mathrm{ppm})$ from the other land-uses/covers. However, the three land uses/covers did not significantly differ from each other in influencing the soil exchangeable $\mathrm{Mg}, \mathrm{Ca}, \mathrm{Na}$ and $\mathrm{C} / \mathrm{N}$ ratio. The people in the study area perceived that Eucalyptus plantations have negative effects on crop yield and soil moisture; this perception correlated with and supported by the results of this study on soil texture and bulk density where Eucalyptus plantations increased the bulk density of the soil which in turn indicates compactness and low moisture holding capacity.
\end{abstract}

Keywords: Eucalyptus species, Monoculture, Experimental plot

DOI: $10.7176 / \mathrm{JEES} / 9-6-05$

Publication date:June $30^{\text {th }} 2019$

\section{INTRODUCTION}

Currently Eucalyptus has become the most planted genus of trees in the world given to its large number of species, i.e. more than five hundred species (Bekele, 2015). Eucalyptus species are native to Australia and have been extensively introduced into other countries because of their fast growth, adaptation to different agro-ecologies \& the escalating demand for paper and ply wood (Teketay, 2003). The genus of Eucalyptus was introduced to East Africa in the late 19th century and by the initials of 1970s (Teketay, 2000). In Ethiopia Eucalyptus species were introduced during the reign of Emperor Menelik II in order to use it as a potential solution to the fuel wood and timber shortage that has been facing the country. Indigenous forests stands, particularly Juniperusprocera,Olea europaea and Podocarpusfalcatus were being depleted in the country due to fuelwood and construction material. After that the residents in Addis Ababa and elsewhere in Ethiopia started growing the species around their homesteads, and then it became one of the most widely planted tree species in the country. Pohjonen \& Pukkala (1990) reported that Eucalyptus globulus Labill has been planted as the main tree species in the central highlands of Ethiopia since 1895 which cover about more than 100,000 hectares of land. Nowadays, it is estimated that, over 500,000hectares of the land is covered by Eucalyptus species plantation in Ethiopia (Abebe and Tadesse, 2014). This places Ethiopia among the ten major Eucalyptus growing countries in the world; these are USA, Ecuador, Colombia, Chile, China, Spain, Israel, Morocco, and South Africa. What is amazing is that more than eighty percent of the total Eucalyptus plantation was established almost within thirty years' time (FAO, 1988). Initially Eucalyptus was introduced in Ethiopia with the purpose of providing multipurpose use and rescues the remaining indigenous forests from being destroyed(Abebe and Tadesse, 2014). They also reported that the profit derived from Eucalyptus is considerably higher than cultivating crops because they are a source of various uses for rural and urban people such as firewood, construction material, medicinal value (Eucalyptus leaves have been used in the treatment of colds), source of income by selling tree biomass such as stem for construction and twigs, leaves and bark for fire wood purpose. It has also indispensable national economic contribution by providing raw materials such as aromatic essential oils, timber, veneer, plywood, and pulp for paper making has yet to be fully exploited (Desaleg\& Tadesse, 2010). Furthermore, Teshome (2009) reported that Eucalyptus has acted as a biological conservation measure combined with terraces and check-dam helps reduce soil erosion and act as a windbreak. As a biological land reclamation tool, the species is the last in the succession of land use. This is because of its adaptability to a wide range of ecological conditions and sites (Abebe and Tadesse, 2014). Therefore, 
it has been vital role to the rehabilitation of abandoned sites and on landscape too degraded to support crops.

Even though, Eucalyptus species have been introduced and extensively planted in different countries for exploiting its potential for fuel wood, timber, pulp and paper and other uses, there are reports of negative environmental impacts in planting Eucalyptus, such as soil degradation and loss of biodiversity (Molina et al., 1991). In South Africa, Tererai et al. (2014) reported that physico-chemical properties, and organic matter content of the soil can be adversely affected if the site is covered with Eucalyptus plantations. Wen et al. (2009) and Zhu et al. (2009) in China also reported that Eucalyptus plantation has a devastating effect on the soil physical and chemical properties as well as on plant biodiversity. A study in Sudan by El-Amin et al. (2001 revealed that Eucalyptus species have an adverse effect of depleting nutrients and production of toxic exudates (allelochemicals) to the soil. Similarly, study in Ethiopia also shows that Nech baharzaf (E.globulus) has higher nutrient depleting effect than the plant type such as cedar and cypress forests (Teketay, 2003).

The study in china by Lane et al. (2004) revealed that Eucalyptus plantation has a negative effect on the reduction of water tables and its availability for irrigation. Study in Ethiopia by Alemie (2009) also indicated that Eucalyptus species have high potential to suck the water from nearby stream than four other natural forest species. Furthermore, she added that Eucalyptus species have a potential to compete with agricultural crops and other natural forest species for soil nutrients, water and light.

Aweto and Moleele (2005) reported that Eucalyptus species added a litter fall that has high carbon to nitrogen ratio. As a result, its decomposition takes long time and does not recycle the macro-nutrient such as phosphorus $(\mathrm{P})$ and nitrogen $(\mathrm{N})$. This is because of the presence of higher concentration of allelopathic chemicals and lignin contents in the plant litter fall, which slow down its decomposition. The allelochemicals endure in the soil for long years and affecting the neighboring crops and plant species (Ferguson et al., 2013). Consequently, Mensah (2016) recommended that riverine vegetation and farm crops should be $15 \mathrm{~m}$ and $6 \mathrm{~m}$ away from Eucalyptus plantation respectively so as to minimize the negative impact.

\section{MATERIALS AND METHODS STUDY AREA CHARACTERISTICS}

The study area is at Entoto Mountain which is part of Gullele Sub city, woreda six of Addis Ababa city Administration. Entoto Mountain is located between latitudes $9^{\circ} 04^{\prime} \mathrm{N}-9^{\circ} 06^{\prime} \mathrm{N}$ and longitudes $38^{\circ} 44^{\prime} \mathrm{E}-$ $38^{\circ} 49^{\prime}$ E. The mountain ridge of Entoto divides two large watersheds, that of the Abay (Blue Nile) to the North and Awash to the South. The topographic feature of the study area is consisting of rolling terrain with average elevation of $2408 \mathrm{~m}$, which ranges from 2000 to $3100 \mathrm{~m}$ asl (GSAEPG, 2010). There is a park called Entoto Park which is intersected by rivers and streams flowing Southwards through valleys providing a variety of rock formations, vegetation and wildlife. The natural vegetation of Etoto Mountain is an Afro-montane forest with woodland and open meadows (Tilahun et al., 1996). In the Southwestern corner, there is a cliff with a waterfall and a cave named "Ye Abba Washa". On the Eastern side, further down the mountain, two valleys form wide gorges known as "NebGedel" and "Jib Gedel" are observed with springs. On the North side, the view over the "Sululta" plain covers an extensive area of undulating shallow valleys and marshy meadows with suitable pasture land (Tilahun et al., 1996). At present, most of the Entoto Mountain is enclosed with eucalyptus globulus plantations, which are commonly used for fuel.

\section{RESEARCH DESIGN}

The research design of this study comprises both experimental and surveying design. The socio- economic activities and level of understanding as well as perception of the communities toward the effects of Eucalyptus plantation on soil properties, soil moisture and crop yields was surveyed using different methods as mentioned bellow under data collection while the soil data collected through measurement from the field was diagnosed experimentally in the laboratory following different scientific procedure.

\section{EXPERIMENTAL SAMPLING DESIGN, LAYOUT AND NUMBER OF SAMPLES}

In manipulative designs the treatments are commonly applied in small strips (or plots) approximately $1 / 4$ acre or $30 \times 30 \mathrm{~m}$; twenty or more samples should be taken from the plot and then composited. If the experimental unit is believed to be homogenous then the treatments can be randomly assigned to plots in a completely random design. More typically some degree of heterogeneity is believed to occur for example, a slight slope across the plot. In this case the treatments are assigned to square or rectangular blocks (Steel and Torrie 1980).

Pennock et al. (2006) also reported that sub-sections of a field would commonly be used if there is a difference in topography (termed landscape-directed soil sampling), parent material, management history, or yield history.

Based on the above idea, there are three experimental plots which are (Agricultural crops, Eucalyptus plantation, and Natural forest). Each of them has an area of $100 \mathrm{~m}$ by $100 \mathrm{~m}$ and divided into three subplots of $100 \mathrm{~m}$ by $33 \mathrm{~m}$, which serve as replications; then soil samples was collected at the depth of $30 \mathrm{~cm}$ for each land uses using a soil auger at 24 sampling points within a block. Therefore, the subplots divided in to three blocks based on 
the topographical differences; then from each field blocks samples were collected using "Z-layout" designs. Soil samples were taken from the four corners and center of each layout. Approximately $1 \mathrm{~kg}$ of composited sample was collected from each location and placed into plastic bags.

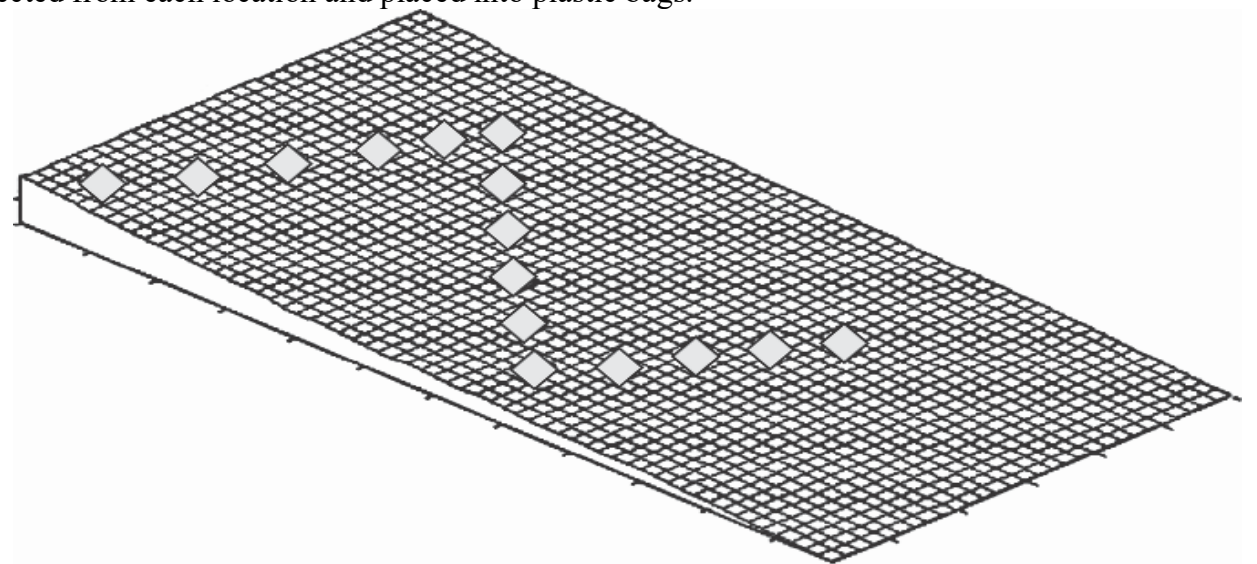

FIGURE 5. EXAMPLE OF A ZIGZAG SAMPLING LAYOUT ON A NEAR-LEVEL SURFACE.

Soil samples would be taken at each point labeled with a diamond shape. Undisturbed soil samples were taken independently from each subplot of land uses with a core sampler of $5 \mathrm{~cm}$ in length and diameter for bulk density determination.

(Pennock et al, 2006) reported that estimation of the number of required samples needs prior knowledge about coefficient of variation (CV) of the property of the subject under investigation to achieve the intended accuracy within an acceptable margin of error at a selected confidence interval. The authors documented estimates of coefficient of variation for various soil properties shows that; the CV for SOC, sand content, clay content ranges from $15-35 \%$ while soil-available $\mathrm{P}$, soil-available $\mathrm{K}$, exchangeable $\mathrm{Ca}, \mathrm{Mg}, \mathrm{K}$, soil nitrate $\mathrm{N}$ range from $35 \%-$ $75 \%$ whereas that of soil $\mathrm{pH}$, silt content, and bulk density could be $<15 \%$. According to (Pennock et al, 2006) also reported that if one assumes a $20 \% \mathrm{CV}$ for investigating SOC, sand content, and clay content from the site; the number of samples needed to achieve a $10 \%$ margin of error at $95 \%$ confidence level are 16 samples per subplot. In such case, there would be three experimental plots with three subplots; the total number of soil sample could be $(16 \times 3 \times 3)=144$ with fifteen parameters. The required number of samples would be calculated using the following formula.

$\mathbf{n}=\frac{(\mathbf{t} 0.05) 2 \times c v 2}{\text { errorr } 2}$ Where,

$\mathrm{n}=$ number of samples

$\mathrm{t} 0.05=\mathrm{t}$ value at 95 confidence level i.e. 1.96

$\mathrm{CV}=$ coefficient of variation,

Error $=$ margin of error $(10 \%)$.

However, such large sized sampling will incur high cost of laboratory resources and time. On the other hand, there is also a risk of loss of statistical accuracy and precision to estimate true population features if data from small number of samples are used. Therefore, it was planned to take composited samples; which are 24 sampling points per composite sample, the total number of sampling points were 216. Then finally there have been 9 composited samples from all land uses. Sampling time has been in February 2018 and samples were collected using appropriately labeled and known weight plastic bags

SAMPLE PREPARATION, SAMPLING PROCEDURE.

Soil samples was collected at the depth of $30 \mathrm{~cm}$ for each land uses using a soil auger at 24 sampling points within a block of $(33.3 \mathrm{mx} 33.3 \mathrm{~m})$. Three composite samples were taken from each of the agricultural plot, Eucalyptus plantation and natural forests plots. The collected soil sample was placed in plastic bags and transported to laboratory. Soil samples were dried in oven dry at $55 \mathrm{c}^{\circ}$; then it was ground and made to pass through $2-\mathrm{mm}$ sieve. After all the gravel, leaf and dead organic residues have been removed; selected representative composite soil samples were sent for physico-chemical analysis.

\section{LABORATORY ANALYSES SOIL TEXTURE}

Soil texture analysis was done using the Bouyoucos hydrometer method (Hinga et al., 1980; Klute, 1986). Ovendry soil sample weighing $30 \mathrm{~g}$ was put in a plastic shaking bottle and $30 \mathrm{ml}$ Calgon (dispersion agent) added. A blank sample (without soil sample) was also prepared (represented reading for blank sample, $\mathrm{Rb}$ ). The mixture was placed on a mechanical shaker and shaken for 3 hours. The suspension was transferred into the sedimentation 
measuring cylinder. The mixture was stirred well using a metal plunger to bring the particles into suspension. By the use of a soil hydrometer, a reading was taken after 40 seconds (represented the first reading, R1). After two hours, the hydrometer was used to take the second reading (R2). The second reading gives the clay content. The calculations were done as follow (equations 3,4 , and 5):

$\%$ Clay $=\frac{R 2-R b}{50} \times 100$ Equation 3

The first reading gives the Silt + Clay

That is $\%$ (Silt + Clay $)=\mathrm{R} 1 / 50 * 100$ Equation 4

Therefore, $\%$ Silt $=$ this reading minus $\%$ clay

$\%$ sand $=100-\%$ (Silt + Clay $)$ Equation 5

After getting the percentage sand, silt and clay, the soil textural triangle was used to classify the soil.

\section{SOIL DRY BULK DENSITY}

The soil bulk density was determined using the Core method prescribed for undisturbed soils (Yerima and Van Ranst., 2005). 1 to $1.5 \mathrm{~cm}$ of soil surface was removed and a core sampler driven into the soil. The soil from around the core sampler was evacuated and the soil beneath could be cut off. Both ends of the core sampler was trimmed and flushed with a straight edge knife. The core sample was oven dried to a constant weight using the WTC Binder Oven at $105 \mathrm{oC}$ for 24 hours. The volume of the core was determined using the following formula:

Where

$\mathrm{V}=$ volume of core $(\mathrm{cm} 3) ; \pi=3.14$;

$\mathrm{r}=$ radius $=$ diameter $/ 2(\mathrm{~cm}) ;$ and $\mathrm{h}=$ height $(\mathrm{cm})$.

$\mathrm{V}=\pi \mathrm{r} 2 \mathrm{~h}\left(\mathrm{~cm}^{3}\right)$

The soil bulk density then calculated using the formula in equation below:

Bulk Density $\left(\mathrm{g} \mathrm{cm}_{-3}\right)=\frac{\text { Wt.of soil core }\left(\text { oven }_{\text {dry basis })}(\mathrm{g})\right.}{\text { Vol.of soil core }(\mathrm{cm} 3)}$

\section{SOIL TOTAL ORGANIC CARBON (TOC)}

Soil total organic carbon was determined by the colorimetric method described by Schulte and Hoskins (2009). Oven-dry soil sample weighing $1 \mathrm{~g}$ was scooped into a $50 \mathrm{ml}$ Erlenmeyer flask. The organic carbon in the soil sample was oxidised by $0.5 \mathrm{M} \mathrm{Na} 2 \mathrm{Cr} 2 \mathrm{O} 7 \cdot 2 \mathrm{H} 2 \mathrm{O}$ and $5 \mathrm{M} \mathrm{H} 2 \mathrm{SO} 4.10 \mathrm{ml}$ of dichromate-sulphuric acid digestion solution was pipetted. A reagent blank without soil also prepared in the same way. This was heated at $150{ }^{\circ} \mathrm{C}$ for 30 minutes to ensure complete oxidation. Barium chloride was added to cool the digest. After mixing thoroughly, the digests was allowed to stand overnight. $10 \mathrm{ml}$ of the clear supernatant was transferred into a colorimeter tube. The soil organic carbon concentration was read on the Specord 200 Plus Ultra Violet Spectrophotometer at 600 $\mathrm{nm}$. The percent of organic matter $(\mathrm{OM})$ in the soil was then estimated using the equation 6 :

$\% \mathrm{OM}=\frac{\% \text { total } \mathrm{C} \times 1.72}{0.58} \ldots \ldots \ldots \ldots \ldots . . .6$;

Where $\mathrm{C}=$ organic carbon concentration

\section{SOIL AVAILABLE PHOSPHORUS}

Soil available phosphorus was determined by the Mehlich double acid method (Justin et al., 2012). An oven-dried soil sample weighing $2.5 \mathrm{~g}$ was put into a $100 \mathrm{ml}$ shaking bottle and $20 \mathrm{ml}$ of the extracting solution (a mixture of $0.1 \mathrm{M} \mathrm{HCl}$ and $0.025 \mathrm{M} \mathrm{H} 2 \mathrm{SO} 4$ ) added. The mixture was shaken for 5 minutes and filtered through a Whatman No. 40 filter paper. A $5 \mathrm{ml}$ of the extract was transferred to a $25 \mathrm{ml}$ flask and diluted to the mark. 5 millilitres of L-Ascorbic Acid was added to each sample and waited for the blue color formation. After 5 minutes the concentration of $\mathrm{P}$ in the filtrate was determined at $830 \mathrm{~nm}$ wavelength using Specord 200 Plus Ultra Violet Spectrophotometer.

\section{SOIL TOTAL NITROGEN (TN)}

Soil TN was determined by the Kjeldahl method as provided by Bashour and Sayegh (2007). Oven-dried soil sample weighing $1 \mathrm{~g}$ was weighed into $500 \mathrm{ml}$ Kjeldahl flask. Five milliliters distilled water was added to wet the soil thoroughly. A scoop of digestion accelerator mixture (sulphuric-salicylic acid mixture) was added to each tube. Five milliliters of conc. H2SO4 was added and the mixture was digested by heating on rack in a fume cupboard gently at first until vigorous effervescence subsided. Heating will continued for one hour after digest was clear with no charred organic matter remaining. The digest was cooled and $20 \mathrm{ml}$ distilled water added and the soil will allow settling. The supernatant solution was decanted into $100 \mathrm{ml}$ volumetric flask. The process was repeated washing the sand particles and quantitatively transferring supernatant to the flask and made to the $100 \mathrm{ml}$ mark. Five millilitres of $40 \% \mathrm{NaOH}$ and $100 \mathrm{ml}$ of distilled water was added. The mixture was distilled, collecting the distillate into $5 \mathrm{ml}$ of the boric acid (H3BO3) solution -indicator mixture. The distillate was titrated with 0.01 $\mathrm{M} \mathrm{H} 2 \mathrm{SO} 4$ from green to pinkish end point and the titre value recorded. The soil TN was calculated using the 
formula in equation 7 :

Calculation

Kjeldahl N $(\%)=\frac{(\mathrm{T}-\mathrm{B}) \mathrm{X} \text { M X } 2.8}{S} \ldots \ldots \ldots \ldots \ldots \ldots \ldots \ldots \ldots \ldots \ldots$ Equation 7

$\mathrm{T}=\mathrm{ml}$ of standard acid with sample titration

$\mathrm{B}=\mathrm{ml}$ of standard acid with blank titration

$\mathrm{M}=$ molarity of sulphuric acid

$\mathrm{S}=$ weight of soil sample in $\mathrm{g}$

SOIL pH

The $\mathrm{pH}$ of the soils was determined using ST 10 OHAUS $\mathrm{pH}$ meter. All $\mathrm{pH}$ measurements were performed using a 1:2.5 (w/v) soil: water ratio by weighing $40 \mathrm{~g}$ of $<2 \mathrm{~mm}$ sieved and oven-dried soil into a $100 \mathrm{ml}$ glass beaker and adding $50 \mathrm{ml}$ distilled water. The soil was mixed with the distilled water and stirred intermittently using a stirrer for 30 minutes before $\mathrm{pH}$ was determined (Anderson and Ingram, 1993).

SOIL EXCHANGEABLE BASES (CA2+, MG2+, NA+, AND K+)

An oven-dried $2 \mathrm{~mm}$ sieved soil sample weighing $4 \mathrm{~g}$ was put into an extraction bottle and $40 \mathrm{ml}$ of $1.0 \mathrm{M} \mathrm{NH} 4 \mathrm{OAc}$ solution at $\mathrm{pH} 7.0$ was added. The bottle with its content was placed in a shaking machine and shaken for one hour. At the end of the shaking, the suspension was centrifuged at $3000 \mathrm{rpm}$ for 5 minutes. The supernatant solution was filtered through No. 40 Whatman filter paper. Twenty four milliliters aliquots of the extract were used for the determination of $\mathrm{Ca}, \mathrm{Mg}, \mathrm{Na}$, and $\mathrm{K}$ (Page et al., 1982). Calcium and magnesium was determined on the 210 VGP Atomic Absorption Spectrophotometer and potassium and sodium by Sherwood 410 Flame Photometer. The Cation Exchange Capacity (CEC) was calculated by summing all the exchangeable cations together as shown in equation 8:

$\mathrm{CEC}=$ Exch. $\mathrm{K}++$ Exch. $\mathrm{Ca} 2++$ Exch. $\mathrm{Mg} 2++$ Exch. $\mathrm{Na}+\ldots \ldots . .$. Equation 8

Where, $\mathrm{CEC}=$ Cation Exchange Capacity, Exch. $=$ Exchangeable

\section{SAMPLING TECHNIQUE AND METHOD OF DATA COLLECTION FOR PERCEPTION ORIENTED ENQUIRY.}

\section{SAMPLING TECHNIQUE}

Entoto Mountain is part of Gulale sub city administration which is selected purposively because of its convenience and historical back ground related with Eucalyptus plantation in Ethiopia. To select respondents from the study area for collecting information about the perception of resident toward the effect of Eucalyptus plantation, the researcher was used stratified sampling techniques based on age and educational level category. Total number of population closest to the study area are estimated to be about 1500, so that it is difficult to administer and conducting interview to all of them. As a result, to obtain the representative and appropriate sampling size, the researcher used Kothari (2004) sample size determination formula.

$\mathbf{n}=\frac{Z p q N}{e^{2}(N-1)+Z^{2} p q}$

$\mathbf{n}=(1.96) \times 0.5 \times 0.5 \times 1500 /(0.1)(1500-1)+(0.196)^{2}, \times 0.5 \times 0.5$

$\mathbf{n}=94$ respondent,

Where: $\mathrm{n}$ : is the sample size for a finite population

$\mathbf{N}$ : Size of population which is the number of households

p: population reliability (or frequency estimated for a sample of size $n$ ), where $p$ is 0.5 which is taken for all developing countries population and $\mathrm{p}+\mathrm{q}=1$

e: margin of error considered is $10 \%$ for this study $(\mathrm{e}=$ precision level assumed to be $(0.1$ or $10 \%)$

$\mathbf{Z} \boldsymbol{\alpha}$ /2: normal reduced variable at 0.05 level of significance $\mathrm{z}$ is 1.96

\section{METHOD OF SOCIO-ECONOMIC DATA COLLECTION}

The study was conducted using primary and secondary data source. The primary data was collected from residents of the study area using questionnaire, interview and physical observation. The questionnaires were closed and open ended types. The secondary data was collected from different offices published or un published materials including annual reports, magazines, journals, books, etc.

\section{DATA ANALYSIS}

The collected peoples' perceptions data through questionnaires, interviews and observations were analyzed and organized by using descriptive statistical method in the form of summaries and narrations. The quantitative data obtained from measurement was analyzed and presented using tables, and figures. Statistical differences between the values of soil properties across the land use types were tested using a one-way analysis of variance (ANOVA) by the statistical package for the social science (SPSS) version 21.0. 
When significant differences were observed, comparisons of means were performed using Tukey at 5\% probability level. Pearson's correlation coefficient was computed to examine the relationship between different soil properties.

\section{RESULT AND DISCUSSION}

Farmers' perception concerning the effect of Eucalyptus plantations' on soil properties and crop yield.

The respondents, both male and female with age ranging from 13 to 47 and educational level varies from nonformal to grade ten (Table 4), perceived that Eucalyptus plantations provide various ecosystem goods (firewood, construction wood), and also have negative effects on neighboring crop yield through shading effect, nutrient and moisture competition, and it dries up freshwater sources (example, springs) via higher evapotranspiration.

Respondents were asked about the reasons why they insisted on and continuing planting Eucalyptus instead of other native plant species despite its perceived negative impacts. They replied that Eucalyptus has good coppicing and, fast or rapid growth abilities and produces large volume of wood within short period of time when compared to any of the native tree species. They also perceived that this fast growth and higher volume of wood production characteristics of Eucalyptus plantations minimize the wood destruction pressure on the remnant natural forest. Even though people in the study area used different tree species, animal manure and electricity as energy source, the most common and dominant one is Eucalyptus plantations (Table 5).

Table 4. Demographic expression of farmers in the study area $(\mathrm{N}=94)$

\begin{tabular}{|c|c|c|c|c|}
\hline $\begin{array}{l}\text { Demographic } \\
\text { information }\end{array}$ & $\%$ Respondents & & & \\
\hline Gender & Male(96) & male(4) & & \\
\hline Age & $\begin{array}{ll}\text { A. }<15 & \text { B. } 15-25 \\
(22) & (30)\end{array}$ & $\begin{array}{l}\text { C. } 25-45 \\
(42)\end{array}$ & $\begin{array}{l}\text { D. } 45< \\
(6)\end{array}$ & \\
\hline Educational status & $\begin{array}{l}\text { A. No formal edu } \\
(20)\end{array}$ & $\begin{array}{l}\text { B. } 1-5 \\
(32)\end{array}$ & $\begin{array}{l}\text { C.6-8 } \\
(35)\end{array}$ & $\begin{array}{l}\text { D.9-10 } \\
(13)\end{array}$ \\
\hline
\end{tabular}

TABLE 5. FARMERS' PERCEPTION CONCERNING TREE PLANTING IN THE LOCALITY (N=94).

\begin{tabular}{|c|c|c|c|c|c|}
\hline $\begin{array}{l}\text { Issues regarding to } \\
\text { trees planting }\end{array}$ & Percentage of res] & & & & \\
\hline Source of energy & $\begin{array}{l}\text { A,Firewood } \\
\text { (Eucalyptus) } \\
(100)\end{array}$ & & $\begin{array}{l}\text { B,Animal manure } \\
(20)\end{array}$ & $\begin{array}{l}\text { C,Electricity other } \\
\text { (16) }\end{array}$ & \\
\hline $\begin{array}{l}\text { Location to plant } \\
\text { Eucalyptus }\end{array}$ & $\begin{array}{l}\text { A,Home } \\
\text { Stead(10) }\end{array}$ & & $\begin{array}{l}\text { B,On marginal land } \\
(46)\end{array}$ & $\begin{array}{l}\text { C,On agricultural } \\
\text { land(4) }\end{array}$ & $\begin{array}{l}\text { D, Along crop } \\
\text { border }(60)\end{array}$ \\
\hline $\begin{array}{l}\text { farmers total area of } \\
\text { land in hectare }\end{array}$ & $\begin{array}{l}\text { A. } 0.25 \text { to } 0.5 \text { ha } \\
\text { (11) }\end{array}$ & & $\begin{array}{l}\text { B. } 0.5 \text { to } 1 \text { ha } \\
\text { (25) }\end{array}$ & $\begin{array}{l}\text { C.above 1ha } \\
(64)\end{array}$ & \\
\hline Purpose of the land & $\begin{array}{l}\text { A,Crop production } \\
\text { (70) }\end{array}$ & & $\begin{array}{l}\text { B,Tree plantation } \\
(40)\end{array}$ & $\begin{array}{l}\text { C, Grazing } \\
(36)\end{array}$ & $\begin{array}{l}\text { D, Other } \\
(9)\end{array}$ \\
\hline $\begin{array}{l}\text { commonly plant } \\
\text { species }\end{array}$ & $\begin{array}{l}\text { A,Eucalyptus } \\
(100)\end{array}$ & & $\begin{array}{l}\text { B,Tid(Junipers } \\
\text { procera) } \\
(16)\end{array}$ & $\begin{array}{l}\text { C,Other } \\
\text { (10) }\end{array}$ & \\
\hline $\begin{array}{l}\text { Reason for Eucalyptus } \\
\text { planting. }\end{array}$ & $\begin{array}{l}\text { A,construction } \\
\text { fuel-wood } \\
(100\end{array}$ & $\&$ & $\begin{array}{l}\text { B,coppicing ability } \\
\text { (24) }\end{array}$ & $\begin{array}{l}\text { C,Rescue remnants } \\
\text { natural forests } \\
(35)\end{array}$ & $\begin{array}{l}\text { D,rapid } \\
\text { growth } \\
(33)\end{array}$ \\
\hline
\end{tabular}

The entire respondents in the study area have a land which ranging from 0.25 to 2 hectares. But most of them have one hector and above. The farmers used their land for different purposes: tree plantation, crop production, and for grazing purpose. Most respondents replied that planting of Eucalyptus at marginal land and along the crop border could be justifiable than on fertile agricultural lands (Table 5). 
TABLE 6. FARMERS' PERCEPTION ABOUT IMPACT OF EUCALYPTUS PLANTATION ON SOIL, CROPS AND WATER SOURCES (N=94).

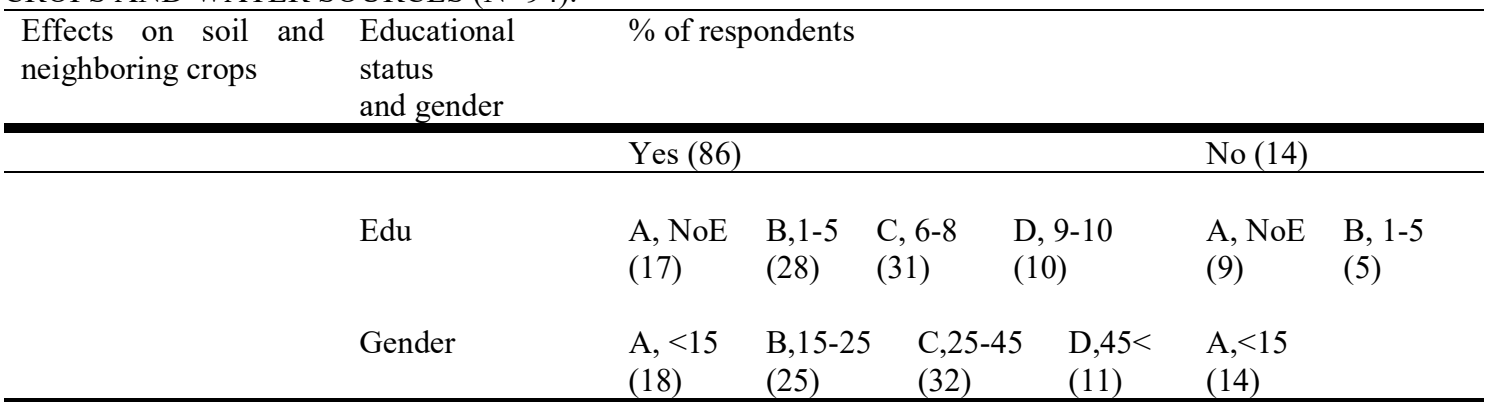

Most farmers in the study area perceived that the Eucalyptus trees affect soil property and crop production through nutrient and moisture competition as Eucalyptus grows faster compared to native plant species, pumps more water from the soil via evapotranspiration and has a shading effect. The study result shows that as the experience and educational level of farmers increase; the awareness of the people towards negative impacts of Eucalyptus plantations on soil and crop production also increased (Table 6). The entire interviewees agreed that Eucalyptus plantation around water sources (example spring water) can cause drying up because of high evapotranspiration rate and fast-growing characteristics of the species. The respondents also explained about the conditions at which the adverse effects would be exacerbated; these are slope of the land and drainage system. Of these most respondents replied that the effect would be pronounced if the area is flat and dry land; and some other people thought at steep land and wet land.

Finally, the respondents recommended the following measures as a solution to minimize the negative impacts. These include careful selection of appropriate species, matching of species with appropriate sites, and planting the Eucalyptus species on unfertile lands as well as intercropping of leguminous species with Eucalyptus plantation.

\section{Effect of Eucalyptus plantations and other land uses on soil physical properties. Effect on soil texture and bulk density}

The soil texture analysis results showed that Eucalyptus plantations had significantly higher effect on soils that increased the sandy and lowered the clay contents. These effects were, however, similar to influences of croplands on soil but differed from natural forests (Figure 6).

The reason behind that the higher sand and lower clay fractions under EP was may be due to the absence of vegetation cover and lack of organic matter. Eucalyptus species produce leaf litter containing allelopathic compounds that are commonly associated with poor under stories due to suppression of co-occurring plant species, which in turn affects the soil aggregates and as a result the finer particles to be washed out through erosion (Demessie et al., 2012). In the same way, cropland soils have higher in sand and lower clay content. This is due to disturbance of the soil during cultivation and removal of clay particles by erosion leaving behind the sand fractions onsite (Abbasi et al., 2007).

Regarding the soil bulk density in the study area, the soil bulk density was significantly affected $(\mathrm{F}=16.8, \mathrm{P}$ $<0.05$ ) by EP than the two land uses (Figure 6). Soils under EP followed by cropland had higher value of BD than the adjacent soil of NF.

These difference are possibly related to the difference of SOM; since the observed correlation $(r=-0.904$, $\mathrm{p}<0.05$ ) indicated that changes in BD values are attributed to change in SOM content (Figure 8). This study was in agreement with Ravina (2012) who found a higher soil bulk density under EP than NF in Brazilian. On the other hand, agricultural soil BD did not show significant differences from the natural forests. However, numerically the overall BD of agricultural soil was different from the natural forests. The difference may be due to cultivation, harvesting of crop residues, trampling by animals foot (Woldeamlak Bewket and Stroosnijder, 2003). This finding was similar with the results of Eyayu Molla et al., (2009) that reported an increase in BD in different land use types as compared to natural forest soils. The result from this study showed that the mean value of BD under natural forest soil was $1.100 \mathrm{~g} \mathrm{~cm}^{-3}$. This idea conformed with Kolay (2000) who reported that bulk density of productive natural soils ranges from 1.1 to $1.5 \mathrm{~g} \mathrm{~cm} .-3$ 
$\mathbf{A}$

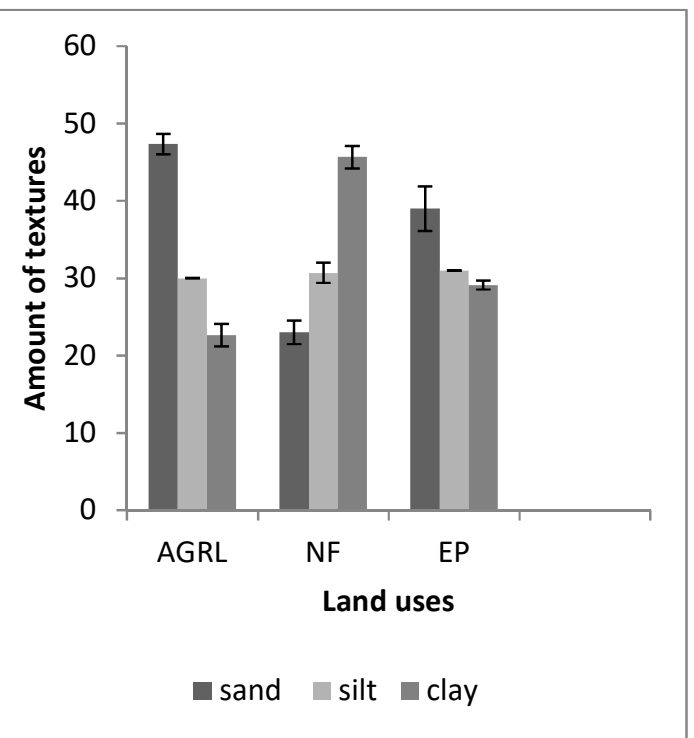

B



$A G R L=A G R I C U L T U R A L ~ L A N D, N F=N A T U R A L$ FOREST, EP $=$ EUCALYPTUS PLANTATION, $B D=B U L K$ DENSITY $\left(G / C M^{3}\right)$

FIGURE 6. SOIL PHYSICAL PROPERTIES OF AGRICALTURAL, EUCLAYPTUS PLANTATION(EP) AND NATURAL FOREST (NF) SOILS.

Effect of Eucalyptus plantations and other land uses on soil chemical properties. Effect on soil exchangeable cations.

Concentrations of $\mathrm{Ca}$ were dominant in the exchange sites of the soil colloidal materials. This was followed by $\mathrm{Mg}, \mathrm{K}$ and $\mathrm{Na}$ in that order (Table 7). Potassium cations under EP was significantly $(\mathrm{F}=92.6, \mathrm{p}<0.05)$ lower than natural forest soils. This is may be due to availability of higher moisture contents under the soil of NFs which increases the movement of these cations to the plant roots (Demessie et al., 2012). The amount of exchangeable cations under the soil of EP was relatively lower than the soil of natural forests (Table 7). This is because of the nutrients immobilizing capacity of Eucalyptus leave litter, especially exchangeable cations. Similarly, the numerical values of exchangeable cations in the agricultural soil were lower than the natural forest soil. This might be due to its continuous losses resulted by cultivation and application of acid forming fertilizers which enhancing the depletion of the nutrients (Baker et al., 1997). However, the contents of exchangeable cations $\mathrm{Ca}, \mathrm{Mg}$ and $\mathrm{Na}$ were not significantly $(\mathrm{p} \geq 0.05)$ affected by land use. This result corroborates with Aweto and Moleele (2005) who reported that soil contained low $\mathrm{pH}$ value leads to the lower concentration of exchangeable cations. Similarly, Jaiyebo (1998) and Bailey et al. (2005) also indicated that soil base cations such as (e.g. $\mathrm{Mg}^{2+}, \mathrm{Ca}^{2+}, \mathrm{K}^{2+}$ ) would be depleted if the acidity of the soil is extremely higher. This is due to replacement of the basic cations by Al3+ and $\mathrm{H}+$ ions.

Soil $\mathrm{pH}$ under $\mathrm{EP}$ was significantly $(\mathrm{F}=37, \mathrm{P} \leq 0.05)$ lower than $\mathrm{NF}$ soils. The causes may arise from Eucalyptus species immobilize soil exchangeable bases, which leads to the increment of the ions such as $\mathrm{Al}+$ and $\mathrm{H}+$ in the soil (Aweto and Moleele 2005). Similarly, the soil $\mathrm{pH}$ level of the agricultural soil was significantly $(\mathrm{F}=37, \mathrm{p} \leq 0.05)$ lower than NF soils (Table 7). This may be due to continuous use of ammonium based fertilizers such as diammonium phosphate ((NH4)2HPO4), urea, potash, and N, K, P (20:10:10). On the other hand, this result were disagree with the findings in turkey by Kizilkaya and Dengiz (2010) who reported the $\mathrm{pH}$ value of soil under cultivated land was significantly higher than soil under natural forest with the value of 7.71 and 6.03 respectively. This difference were may be due to the fact that sustainable agricultural land management practices such as the application of animal droppings, composts, and mulching were implemented in that farm land. 
TABLE 7. EFFECTS OF AGRICULTURAL ACTIVITIES, EUCALYPTUS PLANTATION AND NATIVE PLANTS ON SOIL EXCHANGEABLE CATIONS.

\begin{tabular}{|c|c|c|c|c|}
\hline $\begin{array}{l}\text { Exchangeable } \\
\text { cations \& pH }\end{array}$ & $\begin{array}{l}\text { Agricultural } \\
\text { land }\end{array}$ & $\begin{array}{l}\text { Native plant } \\
\text { species }\end{array}$ & $\begin{array}{l}\text { Eucalyptus } \\
\text { plantations }\end{array}$ & $\begin{array}{l}\mathrm{p}- \\
\text { value }\end{array}$ \\
\hline $\begin{array}{l}\operatorname{Sodium}(\mathrm{Na}) \\
\left(\mathrm{Cmol}(+) \mathrm{Kg}^{-1}\right.\end{array}$ & $0.073 \pm 0.07$ & $0.083 \pm 0.008$ & $0.12 \pm 0.02$ & $\begin{array}{l}0.258 \\
0.392\end{array}$ \\
\hline $\begin{array}{l}\text { Calcium }(\mathrm{Ca}) \\
\left(\mathrm{Cmol}(+) \mathrm{Kg}^{-1}\right.\end{array}$ & $10.72 \pm 0.10$ & $13.78 \pm 0.47$ & $12.22 \pm 3.0$ & $\begin{array}{l}0.831 \\
0.822\end{array}$ \\
\hline $\begin{array}{l}\text { Magnesium(Mg) } \\
\left(\mathrm{Cmol}(+) \mathrm{Kg}^{-1}\right.\end{array}$ & $2.35 \pm 0.03$ & $2.92 \pm 0.14$ & $2.83 \pm 0.82$ & $\begin{array}{l}0.771 \\
0.661\end{array}$ \\
\hline $\begin{array}{l}\text { Potassium }(\mathrm{K}) \\
\left(\mathrm{Cmol}(+) \mathrm{Kg}^{-1}\right.\end{array}$ & $0.43 \pm 0.044$ & $0.85 \pm 0.003$ & $0.33 \pm 0.02$ & $\begin{array}{l}0.097 \\
0.000\end{array}$ \\
\hline $\mathrm{pH}(1: 2.5) \mathrm{H}_{2} \mathrm{O}$ & $5.2 \pm 0.00$ & $5.46 \pm 0.030$ & $5.32 \pm 0.000$ & $\begin{array}{l}0.024 \\
0.006\end{array}$ \\
\hline
\end{tabular}

Effect on soil total nitrogen, total organic carbon, total organic matter, $\mathrm{C} / \mathrm{N}$ ratio, available potassium (K), available phosphorous(P).

Regarding carbon to nitrogen ratio, the $\mathrm{C}$ : $\mathrm{N}$ ratios did not show significant differences among the three land uses. But in general high $\mathrm{C}: \mathrm{N}$ ratios in soils can retard the rate of organic matter and organic nitrogen decomposition by limiting the ability of soil microbial actions. On the other hand, low $\mathrm{C}: \mathrm{N}$ ratios in the soil could accelerate the process of microbial decompositions of organic matter and nitrogen (Salih et al, 1998).

Both available $(\mathrm{K})$ and $(\mathrm{P})$ were significantly $(\mathrm{F}=98.78,8.86, \mathrm{P} \leq 0.05)$ lower under $\mathrm{EP}$ than natural forest soils (Figure 7). Similarly, available $K$ under agricultural soil was significantly $(F=98.78, p \leq 0.05)$ lower than natural forests. However, the concentration of available $\mathrm{P}$ under agricultural soil was not significantly $(\mathrm{P} \geq 0.05)$ different from the natural forest soils. An increase in available $\mathrm{P}$ and $\mathrm{K}$ contents in the natural forest soils could be ascribed to the relative higher organic matter content in these soils as AvP and AvK was strongly associated with SOM ( $r 2$ $=0.875$ and $0.873, \mathrm{p}<0.05)$ respectively (Appendix 5). These findings are in agreement with those of Polglase et al. (1992) who reported that soil under Eucalyptus plantations with the depth of $(0-5 \mathrm{~cm})$ has reduced the concentration of inorganic phosphorus in the soil from an early concentration of 34 to $2.3 \mu$ gg-1 after 16 years of plantations in Australia. Aweto and Moleele (2005) also reported that Eucalyptus species have a capacity of immobilizing phosphorus, and make them inaccessible for plant use. In Ethiopia Alemie (2009) also suggested the same idea which supporting Aweto and Moleele (2000). Furthermore, Berendse (1998) stated that soil $\mathrm{pH}$ of below 5.5, soil micro-nutrients availability increases to levels that are toxic for most plants growth and soluble phosphorus $(\mathrm{P})$ in the soils tends to form insoluble compounds with $\mathrm{Al}$ and $\mathrm{Fe}$ in acidic soils.

The concentrations of TN and TOM under EP were significantly $(F=5.89,55.24, p \leq 0.05)$ lower than the other land uses (Figure 7). Lower OM and TN under EP was arises from limited availability of species compositions which resulting lower availabilities of organic material decompositions (FAO 1998). Similarly, an increase in the level of soil TOM and TN in the natural forest could have been the result of accumulation of plant residues in the upper part of soil depth and their rate of decomposition (Khresat et al., 2008). Conversely, the decline in soil OM contents in the agricultural land could be ascribed to the effect of continuous cultivation that aggravates organic matter oxidation and insufficient inputs of organic substrates from the farming system due to residue removal and presence of water erosion in the study area. These findings corroborate with Yerima and Van Ranst (2005) who were reported that the lower $\mathrm{pH}$ value of the soils leads to slowing the breakdown of litters due to low microbiological activity. Cao et al. (2010) also reported that nitrogen concentration in the soils reveals the rate of breakdown of the plant biomass. Furthermore, Alemie (2009) in Koga watershed also found that TN concentrations decreased under plantations of Eucalyptus species, in Ethiopia. Generally, natural forests have diversified species and high plant litter decomposition than Eucalyptus plant species (Demessie et al., 2012). 

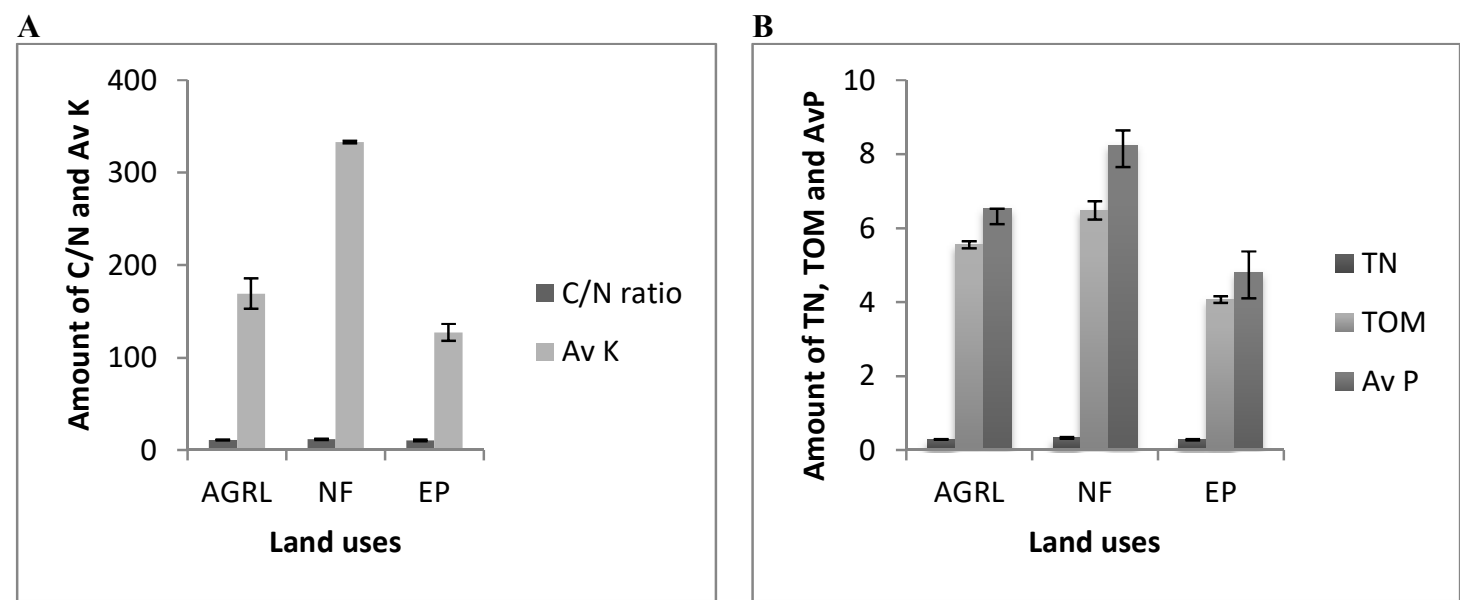

$C / N=C A R B O N$ TO NITROGEN RATIO, AVK=AVAILABLE POTASSIUM (PPM), TN=TOTAL NITROGEN(\%), TOM=TOTAL ORGANIC MATTER(\%), AVP=AVAILABLE PHOSPHOROUS (PPM)

FIGURE 7. SOIL TOTAL NITROGEN, TOTAL ORGANIC CARBON, TOTAL ORGANIC MATTER, C/N RATIO, AVAILABLE POTASSIUM(K), AVAILABLE PHOSPHOROUS(P) OF AGRL, NF, AND EP SOILS
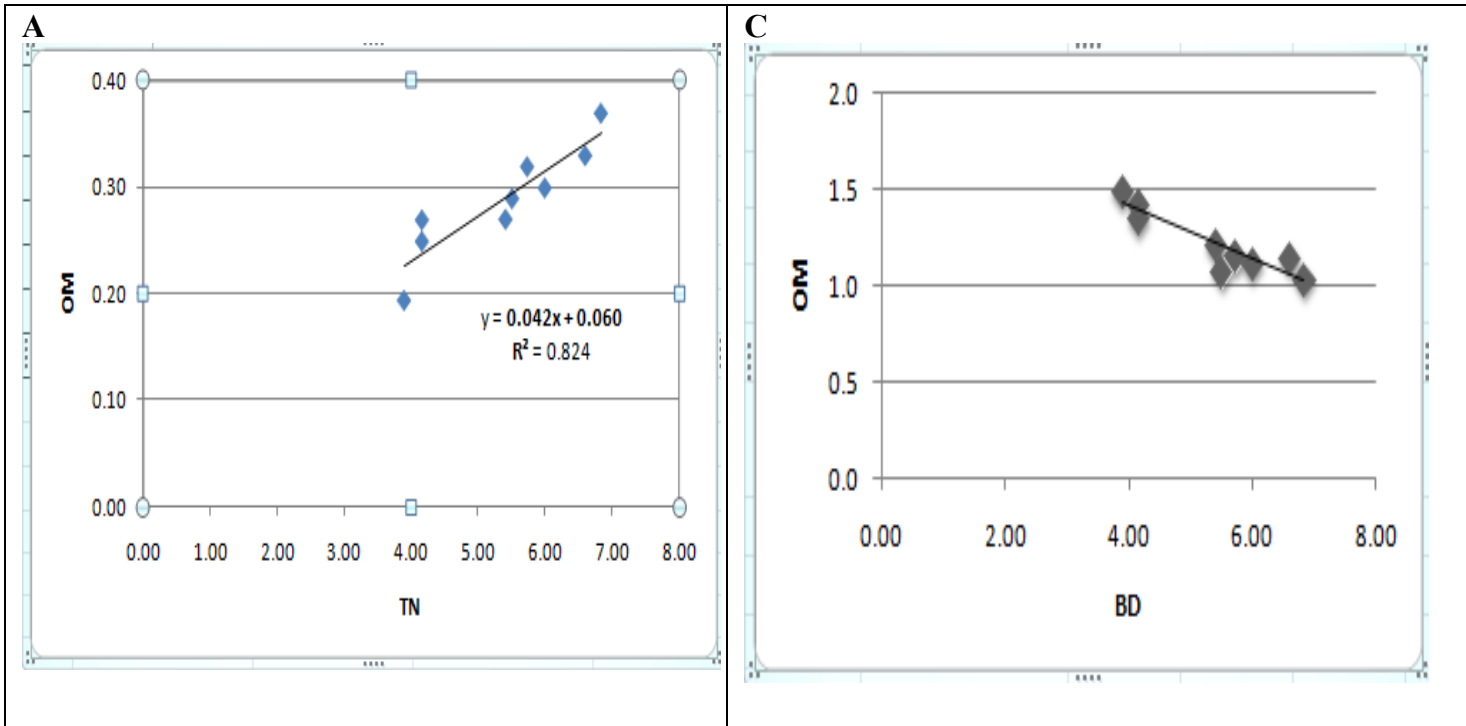

FIGURE 8. A CORRELATION OF ORGANIC MATTER WITH TOTAL NITROGEN AND BULK DENSITY OF THE LAND USES SOIL.

\section{CONCLUSION}

The empirical data obtained from this study revealed that EP following agricultural land with respect to the measured parameters showed changes in soil properties. Eucalyptus plantation caused the depletion of clay fractions, soil organic matter, TN, available K and P, as well as increasing the acidity level of the soil. Similarly, agricultural crops was also has an effect on soil physical and chemical properties when compared with natural forest soils. However, it was not significantly different from Eucalyptus plantation soils except for some parameters eg. BD, OM, pH value. This indicates that in some cases Eucalyptus plantation has higher nutrient depleting effect than agricultural crops. In several cases Eucalyptus plantations and agricultural soil under cultivation had the poorest soil quality than natural forest soil. These variations in soil quality between land use systems are indicators of the risk to sustainable crop production in the study area. The soils acidity levels under the Eucalyptus plantation were also found to be significantly higher than the other two land uses. This became a cause for the depletion of available phosphorus concentration in the soils.

Based on the above empirical fact of the research, the study rejected the null hypothesis that no significant differences exist among Eucalyptus plantation, natural forest and agricultural soil in their effects on soil physical properties. The null hypothesis that no significant difference exist among EP, natural forest and agricultural soil 
in their effects on selected soil macro nutrients was also rejected for soil $\mathrm{pH}$, soil available phosphorus, total nitrogen, total organic carbon, and accepted for soil exchangeable bases such $\mathrm{Ca}, \mathrm{Mg}$, and $\mathrm{Na}$. The study verified that cultivation of Eucalyptus species on fertile land had the tendency to affect the soil physico-chemical properties through nutrient depletion and soil moisture reduction. Similarly, the respondent from the study area suggested that the advantage of Eucalyptus plantation would be justifiable on unfertile and marginal land than fertile agricultural soil. They further recommended that appropriate species selection and matching the site with a preferable Eucalyptus type can contribute for the reduction of the adverse effect on soil quality. On the other hand, Intercropping of leguminous species with Eucalyptus plantation also has an advantage of replenishing the loss of soil nutrient to ensuring the sustainability of Eucalyptus cultivation.

\section{Acknowledgement}

The author acknowledges those friends for supporting for the development of this materials.

\section{REFERENCE}

Abbasi, A. A., \& Younis, M. (2007). A survey on clustering algorithms for wireless sensor networks. Computer communications, 30(14-15), 2826-2841.

Abebe, M., \& Tadesse, W. (2014). Eucalyptus in Ethiopia Risk or Opportunity? Ethiopian Institute of Agricultural Research. Addis Ababa.

Adetunji,M.T.(1996). Field soil tests for NO3, NH4, PO4, K, Ca and Na. University of Abeokuta, Nigeria. In: International Institute of Tropical Agriculture.FAO. Rome

Albaugh, J. M., Dye, P. J., \& King, J. S. (2013). Eucalyptus and water use in South Africa. International Journal of Forestry Research, 2013.

Alem, S., Woldemariam, T., \&Pavlis, J. (2010). Evaluation of soil nutrients under Eucalyptus grandis plantation and adjacent sub-montane rain forest. Journal of Forestry Research, 21(4), 457-460.

Alemie, T. C. (2009). The effect of eucalyptus on crop productivity, and soil properties in the Koga Watershed, Western Amhara Region, Ethiopia (Doctoral dissertation, Cornell University).

Anderson, J. M., \& Ingram, J. S. I. (1993). A Handbook of Methods. Tropical Soil Biology and Fertility, 2nd ed. CAB International, Wallingford.

Arriagada, R., Dunant, A., Pignon, J. P., Bergman, B., Chabowski, M., Grunenwald, D., ... \&Tarayre, M. (2009). Long-term results of the international adjuvant lung cancer trial evaluating adjuvant Cisplatin-based chemotherapy in resected lung cancer. Journal of clinical oncology, 28(1), 35-42.

AWETO*, A. O., \&Moleele, N. M. (2005). Impact of Eucalyptus camaldulensis plantation on an alluvial soil in south eastern Botswana. International journal of environmental studies, 62(2), 163-170.

Baber, S., Ahmad, M. F., \& Bhatti, A. (2006). The effect of Eucalypts camaldulensis on soil properties and fertility. Journal of Agricultural and Biological Science, 1(3), 47-50.

Bailey, S. W., Horsley, S. B., \& Long, R. P. (2005). Thirty years of change in forest soils of the Allegheny Plateau, Pennsylvania. Soil Science Society of America Journal, 69(3), 681-690.

Baker, J. E., Contney, S. J., Gross, G. J., \& Bosnjak, Z. J. (1997). KATPchannel activation in a rabbit model of chronic myocardial hypoxia. Journal of molecular and cellular cardiology, 29(2), 845-848.

Balamurugan, J., Kumaraswamy, K., \&Rajarajan, A. (2000). Effects of Eucalyptus citriodora on the physical and chemical properties of soils. Journal of the Indian Society of Soil Science, 48(3), 491-495.

Bashour, I. I., \&Sayegh, A. H. (2007). Methods of analysis for soils of arid and semi-arid regions. FAO. Rome, Italy. Pp. 1-128

Bekele, T. (2015). Integrated Utilization of Eucalyptus globulus grown on the Ethiopian Highlands and its Contributionto Rural Livelihood: A Case Study of Oromia, Amhara and Southern Nations Nationalities and People's Regional State Ethiopia. International Journal of Basic and Applied sciences, 4(2), 80-87.

Berendse, F. (1998). Effects of dominant plant species on soils during succession in nutrient-poor ecosystems.Biogeochemistry, 42(1-2), 73-88.

Bernhard-Reversat, F., \& Schwartz, D. (1997). Change in lignin content during litter decomposition in tropical forest soils (Congo): comparison of exotic plantations and native stands.ComptesRendus de l'Académie des Sciences-Series IIA-Earth and Planetary Science, 325(6), 427-432.

Bewket, W., \&Stroosnijder, L. (2003). Effects of agroecological land use succession on soil properties in Chemoga watershed, Blue Nile basin, Ethiopia. Geoderma, 111(1-2), 85-98.

Bhatti, A. U., Ali, S., \& Khan, F. (2002). Distribution of some selected soil properties under agroforestry and agricultural crops. Pakistan Journal of Forestry (Pakistan).52(1):39-56.

Calder, I. R., Rosier, P. T., Prasanna, K. T., \&Parameswarappa, S. (1997). Eucalyptus water use greater than rainfall input-possible explanation from southern India. Hydrology and Earth System Sciences Discussions, 1(2), 249-256.

Cao, Y., Fu, S., Zou, X., Cao, H., Shao, Y., \& Zhou, L. (2010). Soil microbial community composition under 
Eucalyptus plantations of different age in subtropical China. European Journal of Soil Biology, 46(2), 128135.

Castro-Díez, P., Fierro-Brunnenmeister, N., González-Muñoz, N., \& Gallardo, A. (2012). Effects of exotic and native tree leaf litter on soil properties of two contrasting sites in the Iberian Peninsula. Plant and Soil, 350(12), 179-191.

Cortez, D., Marin, R., Toledo-Flores, D., Froidevaux, L., Liechti, A., Waters, P. D., ... \&Kaessmann, H. (2014). Origins and functional evolution of $\mathrm{Y}$ chromosomes across mammals. Nature, 508(7497), 488.

Demissie, T. B., Hanssen, K. Ø., Schuler, B., Williams, A. J., Hansen, E., Andersen, J. H., ... \& Meyer, G. (2012). A combined atomic force microscopy and computational approach for the structural elucidation of breitfussin A and B: Highly modified halogenated dipeptides from Thuiariabreitfussi. AngewandteChemie International Edition, 51(49), 12238-12241.

Desalegn, G., \& Tadesse, W. (2010). Characteristics and Potential Uses of Eucalyptus Timber Species Grown in Ethiopia. Eucalyptus Species Management, History, status, and Trends in Ethiopia, 15, 29.

El-Amin, E. A., Diab, I. E., \& Ibrahim, S. (2001). Influence of Eucalyptus cover on some physical and chemical properties of a soil in Sudan. Communications in soil science and plant analysis, 32(13-14), 2267-2278.

FAO, F. (1988). UNESCO soil map of the world, revised legend. World Resources Report, 60, 138.

Ferguson, S. K., Hirai, D. M., Copp, S. W., Holdsworth, C. T., Allen, J. D., Jones, A. M., ... \& Poole, D. C. (2013). Effects of nitrate supplementation via beetroot juice on contracting rat skeletal muscle microvascular oxygen pressure dynamics. Respiratory physiology \& neurobiology, 187(3), 250-255.

Fikre, A. A., \& Demissie, M. (2012). Prevalence of institutional delivery and associated factors in Dodota Woreda (district), Oromia regional state, Ethiopia. Reproductive health, 9(1), 33.

Frimpng, K. A., Afrifa, E. K. A., Ampofo, E. A., \&Kwakye, P. K. (2014). Plant litter turnover, soil chemical and physical properties in a Ghanaian gold-mined soil revegetated with Acacia species. International Journal of Environmental Sciences, 4(5), 987-1005.

Hinga, G., Muchena, F. N., \&Njihia, C. M. (1980). Physical and chemical methods of soil analysis. National Agricultural Research Laboratories, Nairobi, Kenya.

Jagger, P., \& Pender, J. (2003). The role of trees for sustainable management of less-favored lands: the case of eucalyptus in Ethiopia. Forest Policy and Economics, 5(1), 83-95.

Jaiyebo, O. (2003). Women and household sustenance: changing livelihoods and survival strategies in the periurban areas of Ibadan. Environment and Urbanization, 15(1), 111-120.

Jaiyeoba, I. A. (1998). Changes in soil properties related to conversion of savannah woodland into pine and eucalyptus plantations, northern Nigeria. Land Degradation \& Development, 9(3), 207-215.

Jha, M. N., Dimri, B. M., \& Gupta, M. K. (1996). Soil Nutrient Changes Under Different Ages Eucalyptus Monocultures.Indian Forester, 122(1), 55-60..

Justin, M. K., John, K. L., Fred, S. K., \& Peter, K. O. (2012). Comparison of soil phosphorous extraction by Olsen and double acid methods in acid soils of Western Kenya. East African Journal of Pure and Applied Science Vol, 2(1), 1-5.

Khanmirzaei, A., Kowsar, S. A., \&Sameni, A. M. (2011). Changes of selected soil properties in a floodwaterirrigated eucalyptus plantation in the Gareh Bygone plain, Iran. Arid land research and management, 25(1), 38-54.

Khresat, S. E., Al-Bakri, J., \& Al-Tahhan, R. (2008). Impacts of land use/cover change on soil properties in the Mediterranean region of northwestern Jordan. Land Degradation \& Development, 19(4), 397-407.

Kidanu, S., Mamo, T., \&Stroosnijder, L. (2005). Biomass production of Eucalyptus boundary plantations and their effect on crop productivity on Ethiopian highland Vertisols. Agroforestry Systems, 63(3), 281-290.

Kizilkaya, R., \& Dengiz, O. (2010). Variation of land use and land cover effects on some soil physico-chemical characteristics and soil enzyme activity. Zemdirbyste-Agriculture, 97(2), 15-24.

Kolay, A. K., \&Kolay, A. K. (2002). Basic concepts of soil science. New Age International (P) Limited, Publishers. Kothari, C. R. (2004). Research methodology: Methods and techniques. New Age International.

Lane, P. N., Morris, J., Ningnan, Z., Guangyi, Z., Guoyi, Z., \&Daping, X. (2004). Water balance of tropical eucalypt plantations in south-eastern China. Agricultural and Forest Meteorology, 124(3-4), 253-267.

Leite, F. P., Silva, I. R., Novais, R. F., Barros, N. F. D., \& Neves, J. C. L. (2010). Alterations of soil chemical properties by eucalyptus cultivation in five regions in the Rio DoceValley.RevistaBrasileira de Ciência do Solo, 34(3), 821-831.

Lemenih, M. (2010, September). Growing eucalypts by smallholder farmers in Ethiopia. In Proceedings of the Conference on Eucalyptus Species Management, History, Status and Trends in Ethiopia, Addis Ababa, Ethiopia (Vol. 1517).

Lima, A. M. N., Silva, I. R. D., Neves, J. C. L., Novais, R. F. D., Barros, N. F. D., Mendonça, E. D. S., ... \&Leite, F. P. (2008). Soil organic matter fractions after three decades of eucalypt cultivation in the Rio Doce Valley, Brazil. RevistaBrasileira de Ciência do Solo, 32(3), 1053-1063. 
Marx, E. S., Hart, J. M., \& Stevens, R. G. (1996). Soil test interpretation guide. [Corvallis, Or.]: Oregon State University, Extension Service.

Mensah, A. K. (2016). Effects of Eucalyptus Plantation on Soil Physico-Chemical Properties in Thiririka SubCatchment, Kiambu County, Kenya (Doctoral dissertation, Kenyatta University).

Mishra, A., Sharma, S. D., \& Khan, G. H. (2003). Improvement in physical and chemical properties of sodic soil by 3, 6 and 9 years old plantation of Eucalyptus tereticornis: biorejuvenation of sodic soil. Forest Ecology and Management, 184(1-3), 115-124.

Molina, A., Reigosa, M. J., \&Carballeira, A. (1991). Release of allelochemical agents from litter, throughfall, and topsoil in plantations of Eucalyptus globulus Labill in Spain. Journal of Chemical Ecology, 17(1), 147-160.

Montagnini, F. (2000). Accumulation in above-ground biomass and soil storage of mineral nutrients in pure and mixed plantations in a humid tropical lowland. Forest Ecology and Management, 134(1-3), 257-270.

Oyedele, D. J., Awotoye, O. O., \&Popoola, S. E. (2009). Soil physical and chemical properties under continuous maize cultivation as influenced by hedgerow trees species on an alfisol in South Western Nigeria. African Journal of Agricultural Research, 4(8), 736-739

Page, A. L., Miller, R. H., \& Kenney, D. R. (1982). Heavy metals determination, Methods of soil analysis, part 2 , chemical and microbiological properties. American Society of Agronomy, Madison, 8.

Pennock, J. L., \&Grencis, R. K. (2006). The mast cell and gut nematodes: damage and defence. In Parasites and Allergy(Vol. 90, pp. 128-140). Karger Publishers.

Pohjonen, V., \& Pukkala, T. (1990). Eucalyptus globulus in Ethiopian forestry. Forest Ecology and Management, 36(1), 19-31.

Polglase, P. J., Attiwill, P. M., \& Adams, M. A. (1992). Nitrogen and phosphorus cycling in relation to stand age of Eucalyptus regnans F. Muell: III. Labile inorganic and organic P, phosphatase activity and $\mathrm{P}$ availability. Plant and Soil, 177-185.

Polglase, P. J., Attiwill, P. M., \& Adams, M. A. (1992). Nitrogen and phosphorus cycling in relation to stand age of Eucalypus regnans F. Muell. Plant and soil, 142(2), 167-176.

Ravina da Silva, M. (2014). Impact of Eucalyptus plantations on pasture land on soil properties and carbon sequestration in Brazil.Swedish University of Agricultural sciences.

Rhoades, C., \& Binkley, D. (1996). Factors influencing decline in soil pH in Hawaiian Eucalyptus and Albiziaplantations.Forest Ecology and Management, 80(1-3), 47-56.

Robertson, G. P. (Ed.). (1999). Standard soil methods for long-term ecological research (Vol. 2). Oxford University Press on Demand.

Salih, O. K., Topcuoğlu, M. Ş., Çelik, Ş. K., Ulus, T., \& Tokcan, A. (1998). Surgical treatment of hydatid cysts of the lung: analysis of 405 patients. Canadian journal of surgery, 41(2), 131.

Schulte, E. E. (1995). Recommended soil organic matter tests. Recommended Soil Testing Procedures for the North Eastern USA. Northeastern Regional Publication, (493), 52-60.

Schulte, E. E., \& Hoskins, B. (2009). Recommended soil testing procedure for the northeastern United States. Newark (DE): University of Delaware, 63-74.

Steel, R. G., Torrie, J. H., \& Dickey, D. A. (1980). Principles and procedures of statistics: A biometrical approach. McGraw-Hill, New York. Principles and procedures of statistics: A biometrical approach. 2nd ed. McGrawHill, New York.

Teketay, D. (2000). Facts and experiences on Eucalypts in Ethiopia and elsewhere: Ground for making life informed decisions. Walia, 2000(21), 25-46.

Teketay, D. (2003, June). Experience on Eucalyptus plantations in Ethiopia. In Forum on Eucalyptus Dilemma (Vol. 5, pp. 34-48).

Tererai, F. (2012). The effects of invasive trees in riparian zones and implications for management and restoration: Insights from Eucalyptus invasions in South Africa (Doctoral dissertation, Stellenbosch: Stellenbosch University).

Tererai, F., \& Wood, A. R. (2014). On the present and potential distribution of Ageratinaadenophora (Asteraceae) in South Africa. South African Journal of Botany, 95, 152-158.

Teshome, T. (2009). Is Eucalyptus ecologically hazardous tree species. Ethiopian e-journal for research and innovation foresight, 1(1), 128-134.

Tilahun, S., Edwards, S., \&Egziabher, T. G. (1996). Important bird areas of Ethiopia: a first inventory. Addis Ababa: Ethiopian Wildlife and Natural History Society.

Tobias, O. (2004). Social and environmental issues on the removal of fuel-wood and Litter from Eucalyptus stands around Addis Ababa, Ethiopia. Swedish University of Agricultural Sciences, SLU External Relations, Uppsala, 27pp.

URGESSA, H. (2017). Diversity and Relative Abundance of Birds at Entoto Mariam Church Groves (Doctoral dissertation, Addis Ababa University).

Vitousek, P. M., Turner, D. R., \&Kitayama, K. (1995). Foliar nutrients during long-term soil development in 
Hawaiian montane rain forest. Ecology, 76(3), 712-720.

Wen, Y., Zheng, X., Li, M., Xu, H., Liang, H., Huang, C. ... \& He, B. (2009). Effects of eucalypt plantation replacing Masson pine forest on soil physiochemical properties in Guangxi, southern China. Journal of Beijing Forestry University, 31(6), 145-148.

Yerima, B. P., \& Van Ranst, E. (2005). Introduction to soil science: soils of the tropics. Trafford Publishing.

Yuanzhao, H. (2006). Understanding Scientifically the Issue of Developing Fast-growing and High-yielding Eucalypt Plantation in South China. World Forestry Research, 19(3), 71. Florenzano (1956) who found that the nitrifying bacteria were very low under Eucalyptus plantation litter.

Zhang, D., Zhang, J., Yang, W., \& Wu, F. (2012). Effects of afforestation with Eucalyptus grandis on soil physicchemical and microbiological properties. Soil Research, 50(2), 167-176. 